\title{
Fabrication, Structure and Mechanical and Ultrasonic Properties of Medical Ti6Al4V Alloys Part I: Microstructure and Mechanical Properties of Ti6A14V Alloys Suitable for Ultrasonic Scalpel
}

\author{
Zheyu $\mathrm{He}^{1,2}$, Hao $\mathrm{He}^{2, *}$, Jia Lou ${ }^{3}$, Yimin $\mathrm{Li}^{1,2}$, Dongyang $\mathrm{Li}^{1}$, Yongzhi Chen ${ }^{1}$ and \\ Shaojun Liu ${ }^{1, *}$ \\ 1 State Key Laboratory for Powder Metallurgy, Central South University, Changsha 410083, China; \\ holmes416@csu.edu.cn (Z.H.); liyimin333@163.com (Y.L.); dongyangl@csu.edu.cn (D.L.); \\ csuchen@csu.edu.cn (Y.C.) \\ 2 Research Center for Materials Science and Engineering, Guangxi University of Science and Technology, \\ Liuzhou 545006, China \\ 3 School of Materials Science and Engineering, Xiangtan University, Xiangtan 411105, China; \\ lou3166@xtu.edu.cn \\ * Correspondence: 100001865@gxust.edu.cn (H.H.); liumatthew@csu.edu.cn (S.L.)
}

Received: 12 December 2019; Accepted: 16 January 2020; Published: 19 January 2020

\begin{abstract}
Ti6Al4V alloy has been considered as a key component used in ultrasonic scalpels. In this series of papers, the fabrication, structure, and mechanical and ultrasonic properties of medical Ti6Al4V alloys suitable for ultrasonic scalpel are studied systemically. These alloys with low elastic modulus and present a typical bimodal microstructure with relatively high $\beta$ phase content $(\sim 40 \%)$ and lamellar $\alpha$ thickness of $\leq 0.9 \mu \mathrm{m}$. In the first paper, the relationship between the microstructure and mechanical properties of hot-rolled Ti6Al4V alloys treated by heating treatment is discussed. In the second paper, the dependence of the ultrasonic properties on the microstructure of the heat-treated Ti6Al4V alloys is reported. With increasing solid solution temperature, the content and size of the primary $\alpha$ phase decrease. In contrast, the content and size of the lamellar $\alpha$ phase increase. Additionally, the $\beta$ phase content first increases and then decreases. The microstructure of Ti6Al4V alloys could be slightly changed by aging treatment. When the solid solution treatment temperature increases to $980^{\circ} \mathrm{C}$ from $960^{\circ} \mathrm{C}$, the average size of the lamellar $\alpha$ phase in the alloys increases by $1.1 \mu \mathrm{m}$. This results in a decrease in the average yield strength $(93 \mathrm{MPa})$. The elastic modulus of alloys is mainly controlled by the $\beta$ phase content. The microstructure of alloys by solution-treatment at $960{ }^{\circ} \mathrm{C}$ shows the highest $\beta$ phase content and lowest average elastic modulus of $99.69 \mathrm{GPa}$, resulting in the minimum resonant frequency $(55.06 \mathrm{kHz})$ and the highest average amplitude $(21.48 \mu \mathrm{m})$ of the alloys at the length of $41.25 \mathrm{~mm}$.
\end{abstract}

Keywords: medical Ti6Al4V alloys; ultrasonic scalpel; heat treatment; ultrasonic properties; tensile strength; elastic modulus

\section{Introduction}

Since the 1990s, ultrasound surgery operation has become widely used in the field of biomedicine. The development of an efficient, precise, and flexible ultrasonic scalpel (UAS) has become a hot topic ever since [1]. The ultrasonic scalpel system consists of three parts: the ultrasonic generator, transducer, and scalpel. Ultrasonic vibrations generated by the transducer excite a resonant horn and provide the required oscillatory displacement at the tuned ultrasonic frequency in the scalpels [2]. The scalpel is 
a direct-acting workpiece, which requires it present not only good biocompatibility and mechanical properties, but also high ultrasonic energy utilization and large amplitude displacement [3]. Annealed Ti6Al4V is commonly used for ultrasonic scalpel due to its high elastic strain limit, low acoustic attenuation, and biocompatibility [4].

Recent studies [4-7] show that there is a close relationship between the ultrasonic parameters and the microstructure of titanium alloys. Wilkie et al. [4] fabricated five distinct kinds of the microstructure of Ti6Al4V alloys ultrasonic scalpel through heat treatment. They further concluded that the samples with the equiaxial structure show better acoustic properties and higher acoustic attenuation than the alloys with fully lamellar samples. Lobkis et al. [5] reported that the ultrasonic properties of the Ti-based alloys show a strong frequency-dependence of backscattering on the microstructure. Hector et al. [6] showed that the ultrasonic attenuation was different between Widmanstätten and equiaxed microstructures of Ti6Al4V alloy, which was mainly attributed to the scattering loss due to the precipitation of $\mathrm{Ti}_{3} \mathrm{Al}$ particles homogeneously distributed in the $\alpha$ phase. Bhattacharjee et al. [7] studied the ultrasonic attenuation of near- $\alpha$ titanium alloy and found that medical Ti alloys with larger micro-textured microstructure present higher attenuation than those with smaller micro-textured microstructure.

It is well known that the microstructure of titanium alloys can be influenced significantly by the composition, processing, and heating treatment [8-10]. For Ti6Al4V alloys, various microstructures can be obtained by different heat treatments based on the $\beta$-transus temperature [11-13]. Matsumoto et al. [14-17] fabricated ultrafine-grained structure (UFG) of Ti6Al4V alloys through different heat treatment at $800^{\circ} \mathrm{C}$. Although the UFG alloys exhibit low-temperature superplasticity, the plasticity at room temperature is still very poor ( 1\% elongation). Ren et al. [18] obtained a bimodal microstructure of Ti6Al4V alloys by annealing below the $\beta$-transition point. Further investigation showed that the plasticity and strength of alloys are closely related to the content of the primary $\alpha$ phase. In contrast, Peng et al. [19] reported on the fabrication of the Widmannstatten structure of Ti6Al4V-DT alloys by annealing in the $\beta$ phase region. It was found that the strength and plasticity of alloys decrease with increasing test temperature. Obviously, the heat treatment is an effective way to tailor the microstructure of the alloys.

Additionally, as for two-phase titanium alloys, factors that influence the mechanical properties include the volume fraction of transformed $\beta$ phase, size of prior $\beta$ grain, primary $\alpha$ phase, secondary $\alpha$ phase, etc. $[20,21]$. However, conclusions made by different researchers often are inconsistent. Peng et al. [22] found that the strength of Ti6Al4V alloys is related to the primary $\alpha$ phase content in the alloys. In contrast, Guo et al. [23] concluded that the tensile strength of alloys has very low dependence on the primary $\alpha$ phase content. However, the dependence of the tensile ductility on the primary $\alpha$ content is strong. In contrast, Vrancken et al. [24] showed that the key factor affecting the strength of Ti6Al4V alloys is the size of $\alpha$ and $\beta$ phases. It is found that the $\sigma_{\mathrm{y}}$ and UTS of Ti6Al4V alloys decrease while the fine needle-like $\alpha$ phase changes into a coarser mixed structure of $\alpha+\beta$ phases. Niinomi et al. [25] found that the strength of Ti6Al4V alloys increases as the size of $\beta$ grain increases.

The ultrasonic properties of medical Ti alloys can be significantly improved by adjusting the microstructure of Ti alloys. However, very little attention has been paid to the influence of the fabrication processing and structure on the ultrasound properties of the Ti6Al4V alloys. There is still a lack of systematic studies on the relationship between the phase content, size, and mechanical and ultrasonic properties of Ti6Al4V alloy. These two papers aim to prepare Ti6Al4V alloys with significantly different microstructure combining the solid solution with aging treatment. Special attention is paid to the clarification of the mechanisms that are helpful for developing low-cost and highly efficient flexible ultrasonic scalpel (FUS) tools. In the first paper, special attention is paid to the relationship between the microstructure and mechanical properties of the Ti6Al4V alloys. In the second paper, further study will focus on the influence of microstructure on ultrasonic properties. 


\section{Experiments}

Table 1 lists the chemical composition of the Ti6Al4V alloys in the present investigation. As shown in Figure 1, the $\beta$ and $\alpha$ phase transus temperature of the Ti6Al4V alloys are $970.2{ }^{\circ} \mathrm{C}$ and $598.1{ }^{\circ} \mathrm{C}$, respectively. Cylinder samples $(\varnothing 8.5 \times 60 \mathrm{~mm})$ cut from the as-received round bar and their microstructure are shown in Figure 2. In general, the microstructure of Ti6Al4V alloys contains a large number of the $\alpha$ phase and a small number of the $\beta$ phase evenly distributed between the $\alpha$ phases. However, the microstructure along the axial and radial direction is quite different. As shown in Figure $2 \mathrm{a}, \mathrm{b}$, when it is viewed from the radial direction, a large number of the equiaxial $\alpha$ grain with particle size $\sim 5-10 \mu \mathrm{m}$ can be observed, and the $\alpha$ phase is interspersed with the transformed $\beta$ phase. In contrast, when it is viewed from the axial direction, the microstructure has an elongated $\alpha$ phase and intergranular transformed $\beta$ phase, as shown in Figure $2 c, d$, respectively. The difference between the radial and axial directions of the microstructure of as-received specimens is due to the hot-rolling process. However, since the ultrasonic scalpel longitudinal vibration along the axial in the clinics, this study mainly focuses on the microstructure and properties of the Ti6Al4V alloys along the axial direction.

Table 1. Chemical composition of as-received Ti6Al4V alloy.

\begin{tabular}{cccccccc}
\hline $\mathrm{Ti}$ & $\mathrm{Al} / \%$ & $\mathrm{~V} / \%$ & $\mathrm{Fe} / \%$ & $\mathrm{C} / \%$ & $\mathrm{~N} / \%$ & $\mathrm{H} / \%$ & $\mathrm{O} / \%$ \\
\hline Reminder & 6.05 & 4.61 & 0.25 & 0.08 & 0.05 & 0.012 & 0.18 \\
\hline
\end{tabular}

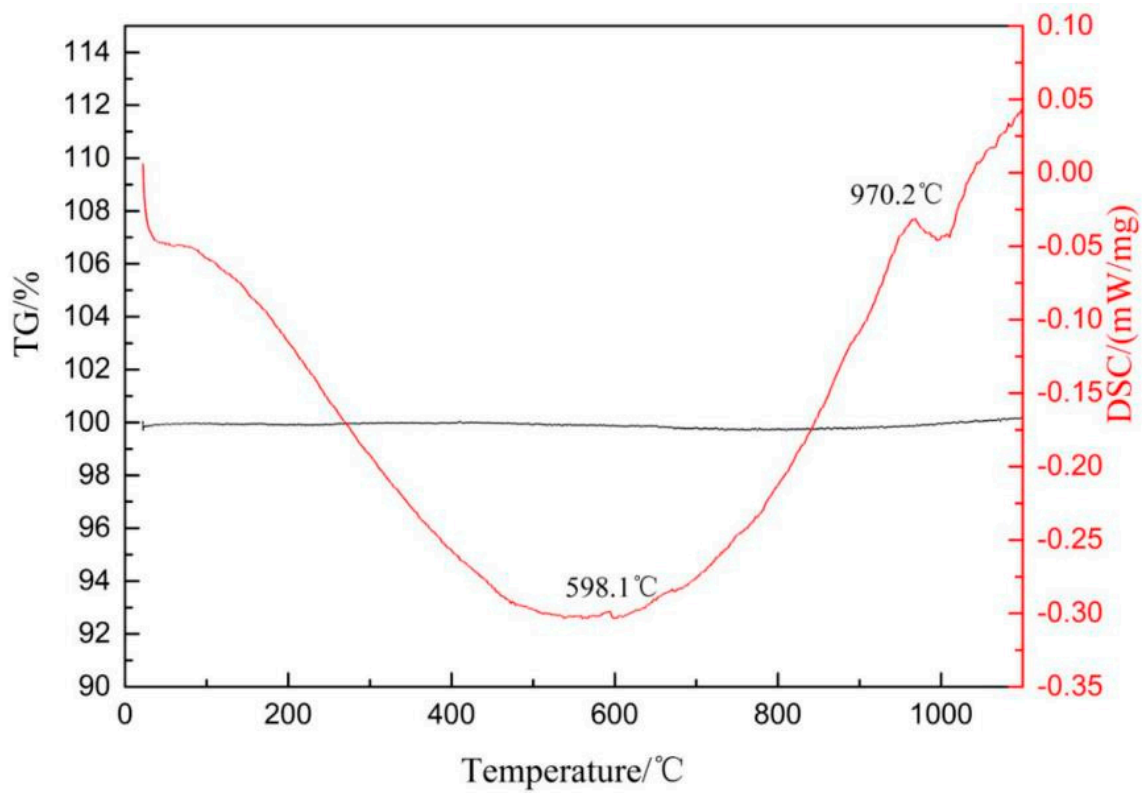

Figure 1. DSC-TG graph of as-received Ti6Al4V alloy.

Heat treatment typically includes solution treatment and aging treatment, as shown in Table 2 . The solution treatment is in a range from $920^{\circ} \mathrm{C}$ to $980^{\circ} \mathrm{C}$ for $1 \mathrm{~h}$, followed by air cooling (AC, the cooling rate at about $0.5^{\circ} \mathrm{C} / \mathrm{s}$ ) to achieve different microstructures. The solid solution specimen treated at $960{ }^{\circ} \mathrm{C}$ was further subjected to additional aging treatment for $2 \mathrm{~h}$ in a range from $600{ }^{\circ} \mathrm{C}$ to $750{ }^{\circ} \mathrm{C}$, and then air cooling. Fifteen samples were used for each heat treatment condition for the subsequent tests. The as-received and heat-treated specimens were ground with $\mathrm{SiC}$ papers and then polished with a $\mathrm{SiO}_{2}$ pyrolysis suspension and etched with reagent $10 \% \mathrm{HF}+40 \% \mathrm{HNO}_{3}+50 \% \mathrm{H}_{2} \mathrm{O}$ solution for 5-10 s at room temperature. The microstructure of Ti6Al4V alloys was observed by Leica DM2700M optical microscope (Leica Microystems, Weztlar, Germany) and further analyzed by VEGA3 LMH/LMU scanning electron microscope (TESCAN ORSAY HOLDING, a.s., Brno, Czech Republic). 

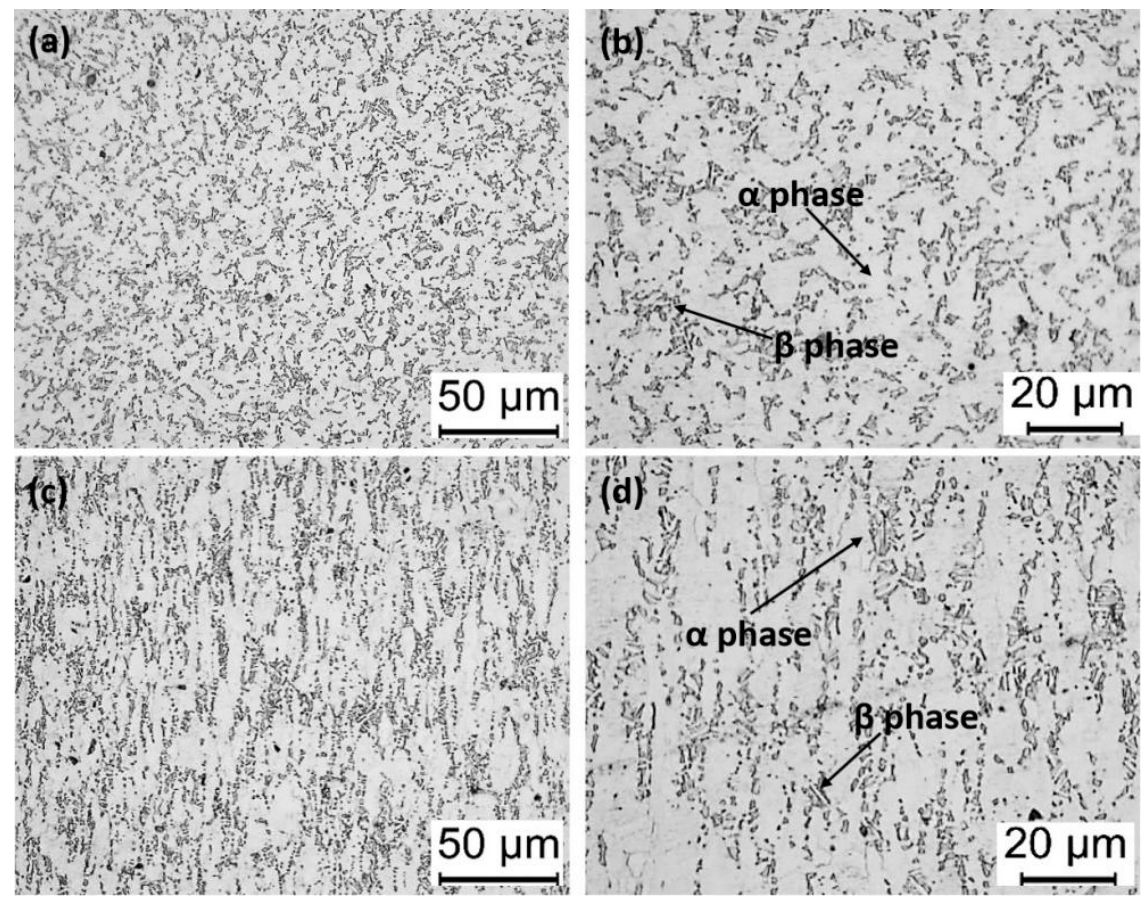

Figure 2. Microstructure of as-received Ti6Al4V alloy $(\mathbf{a}, \mathbf{b})$ viewed from the radial direction and $(\mathbf{c}, \mathbf{d})$ viewed from the axial direction.

Table 2. Heat treatment scheme of various specimens.

\begin{tabular}{cc}
\hline Specimen No. & Heat Treatment \\
\hline A & $920^{\circ} \mathrm{C}, 1 \mathrm{~h}, \mathrm{AC}$ \\
B & $940{ }^{\circ} \mathrm{C}, 1 \mathrm{~h}, \mathrm{AC}$ \\
C & $960^{\circ} \mathrm{C}, 1 \mathrm{~h}, \mathrm{AC}$ \\
D & $980^{\circ} \mathrm{C}, 1 \mathrm{~h}, \mathrm{AC}$ \\
E & $\left(960^{\circ} \mathrm{C}, 1 \mathrm{~h}, \mathrm{AC}\right)+\left(600^{\circ} \mathrm{C}, 2 \mathrm{~h}, \mathrm{AC}\right)$ \\
F & $\left(960^{\circ} \mathrm{C}, 1 \mathrm{~h}, \mathrm{AC}\right)+\left(650^{\circ} \mathrm{C}, 2 \mathrm{~h}, \mathrm{AC}\right)$ \\
G & $\left(960^{\circ} \mathrm{C}, 1 \mathrm{~h}, \mathrm{AC}\right)+\left(700^{\circ} \mathrm{C}, 2 \mathrm{~h}, \mathrm{AC}\right)$ \\
H & $\left(960^{\circ} \mathrm{C}, 1 \mathrm{~h}, \mathrm{AC}\right)+\left(750^{\circ} \mathrm{C}, 2 \mathrm{~h}, \mathrm{AC}\right)$ \\
\hline
\end{tabular}

The macro and micro texture of the $\alpha$ phase was measured by the D8 Bruker XRD system (Bruker AXS, Oestliche, Germany) and NordlysNano SEM (Oxford Instruments plc, Abingdon, UK) with an Oxford EBSD (Electron Backscattered Scattering Detection) detector, respectively. The specimens for EBSD were prepared by mechanically grounding and polishing, and then electro-polished in a solution of $6 \%$ perchloric acid, $34 \%$ butarol, and $60 \%$ carbinol at $45 \mathrm{~V}$ and $-40{ }^{\circ} \mathrm{C}$ for $15 \mathrm{~s}$. The EBSD testing angle is $70^{\circ}$, the accelerating voltage and acquisition speed of the test are $20 \mathrm{kV}$ and $11.27 \mathrm{~Hz}$, respectively. The EBSD orientation maps, pole figure and inverse pole figure maps were analyzed by HKL Channel 5 software (Channel 511 b-win7 32). The $\alpha$ and $\beta$ content and their size of each in Ti6Al4V alloys were further analyzed by Image J (v 1.8.0) software according to the GB/T 6394-2017 specification [26].

Samples were cut from the as-received and heat-treated specimens along the rolling direction and machined into the tensile specimens. Then subjected to tensile tests using the WDW-100G computerized Instron testing system with the maximum testing force of $100 \mathrm{kN}$ at a strain rate of $0.01 \mathrm{~s}^{-1}$ according to the GB/T 228.1-2010 specification [27]. The results of tensile tests were taken from 3 tensile specimens in order to guarantee the reliability of experimental results. The elastic modulus was determined by DTM-II Dynamic Elastic Modulus Tester (Xiangtan Instrument Co., Ltd., Xiangtan, China) according 
to the GB/T 22315-2008 specification [28]. The tensile strength, elastic modulus, and elongation of the as-received Ti6Al4V alloys are $986.42 \mathrm{MPa}, 110.18 \mathrm{GPa}$, and $15.5 \%$, respectively.

\section{Results and Discussion}

\subsection{Microstructure and Mechanical Properties after Solution Treatment}

Figure 3 shows the microstructure of the Ti6Al4V alloys along the axial direction after different solution treatments. After solid-solution treatment, the microstructure contains primary $\alpha$, lamellar $\alpha$, and transformed $\beta$ phase. It is observed that the primary $\alpha$ phase in the Ti6Al4V alloys treated by solid solution treatment at $920^{\circ} \mathrm{C}$ loses its orientation and evolves into an equiaxial shape. When the solid solution treatment temperature increases, the microstructure of as-treated Ti6Al4V alloys gradually transforms from equiaxial to bimodal. The microstructure of the as-treated specimen at $980{ }^{\circ} \mathrm{C}$ that is above the $\beta$ transus temperature presents the Widmannstatten structure characteristics, as shown in Figure $3 \mathrm{~d}$. This is consistent with the reported solid solution treatment parameters obtaining two-phase Ti6Al4V alloys with different microstructures [12].
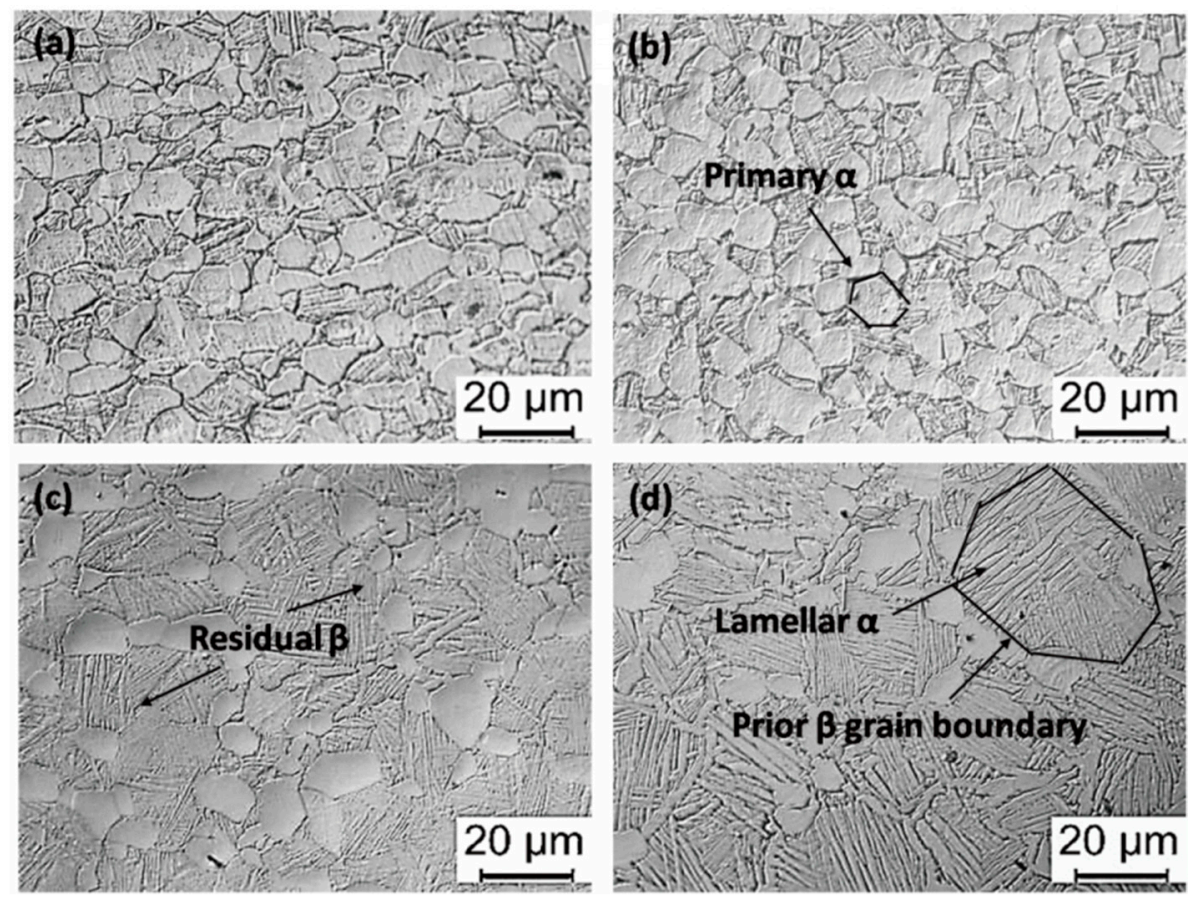

Figure 3. Metallographic image of microstructure obtained by different solution treatments (a) $920{ }^{\circ} \mathrm{C}$ $\times 1 \mathrm{~h}, \mathrm{AC}$; (b) $940^{\circ} \mathrm{C} \times 1 \mathrm{~h}, \mathrm{AC}$; (c) $960^{\circ} \mathrm{C} \times 1 \mathrm{~h}, \mathrm{AC}$; and (d) $980^{\circ} \mathrm{C} \times 1 \mathrm{~h}, \mathrm{AC}$.

The phase composition and grain size of treated Ti6Al4V alloys are shown in Figure 4. As the solid solution treatment temperature increases, the content and grain size of the primary $\alpha$ phase in the alloys decrease. However, a reverse trend is observed for the lamellar $\alpha$ phase in the treated alloys where the prior $\beta$ grain grows and the $\beta$ phase content first rises and then falls. A maximum value of $40.2 \%$ is observed when the alloys are treated by solid solution treatment at $960^{\circ} \mathrm{C}$. It was reported [29] that the higher the solid solution treatment temperature, the lower the equiaxial $\alpha$ content and the larger the lamellar $\alpha$ thickness. These observations are consistent with the present investigation. It is well known that the Ti6Al4V alloys exhibit an $\alpha$ phase (hcp) at low temperature, which can transform into a $\beta$ phase (bcc) at elevated temperature [20]. The phase transformation during heating $(\alpha \sim \beta)$ and cooling $(\beta \sim \alpha)$

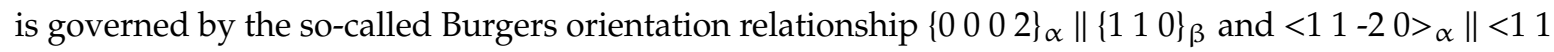
$1>_{\beta}$ [29]. There are 12 possible $\alpha$ orientations that can transform from a single parent $\beta$ grain during $\beta \sim \alpha$ phase transformation while cooling so that the microstructure of alloys exhibit different shapes 
of $\alpha$ phase (equiaxial, lamellar et al.) and residual $\beta$ phase after solid solution treatment. During heating below the $\beta$ transus $\left(970.2{ }^{\circ} \mathrm{C}\right.$ in this article), the higher the solution temperature is, the more $\alpha$ phase is transformed into $\beta$ phase. This makes the residual $\beta$ phase reach the maximum value of about $40 \%$ in $960{ }^{\circ} \mathrm{C}$ solid solution treated specimen by air cooling. However, when the solid solution temperature exceeds the $\beta$ transus temperature, the $\alpha$ phase completely transforms into the $\beta$ phase. There is sufficient time for metastable $\beta$ phase transformed into lamellar $\alpha$ during air cooling, resulting in a decrease in the residual $\beta$ phase content and the further increase in the thickness of lamellar $\alpha$. Therefore, as the solution temperature rises from $960{ }^{\circ} \mathrm{C}$ to $980{ }^{\circ} \mathrm{C}$, the $\beta$ phase content decreases from $40.2 \%$ to $25.2 \%$, while the content and thickness of lamellar $\alpha$ phase increase to $47.6 \%$ from $23.7 \%$ and to $1.63 \mu \mathrm{m}$ from $0.836 \mu \mathrm{m}$, respectively.
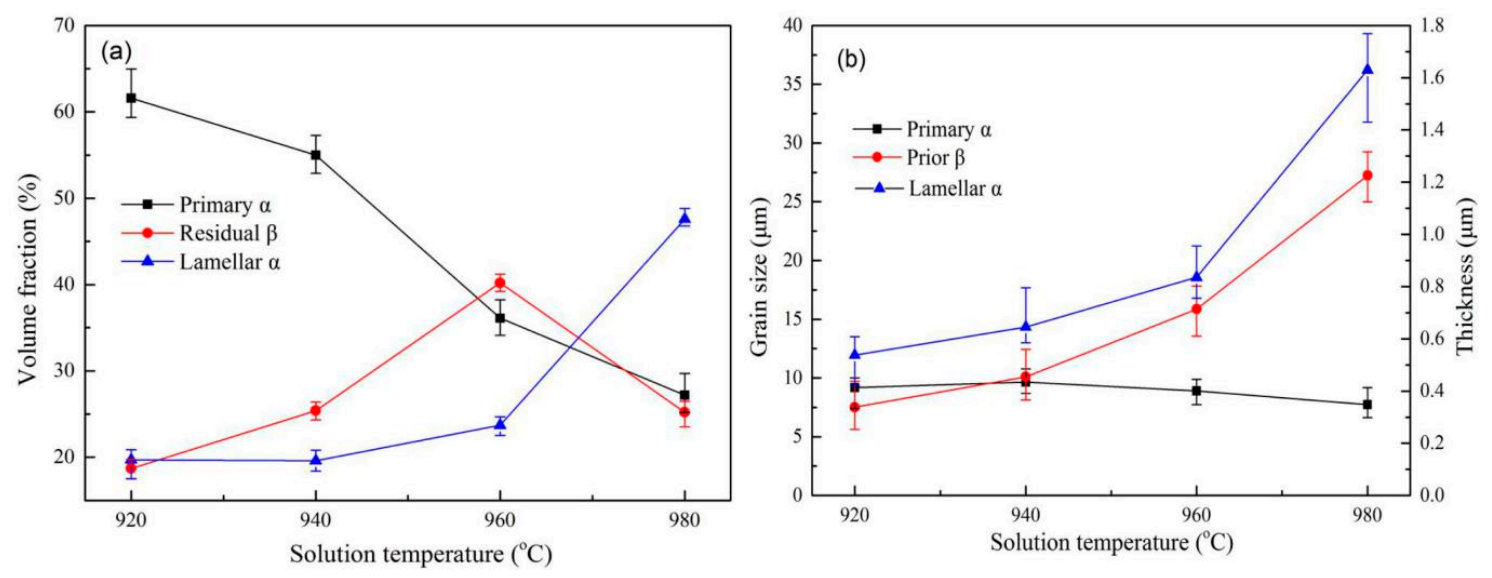

Figure 4. Microstructure statistics (a) volume fraction of $\alpha, \beta$ phase under different solution temperature and (b) grain size and thickness of $\alpha, \beta$ phase under different solution temperature.

Figure 5 shows the dependence of the mechanical properties of Ti6Al4V alloys treated by solid solution treatment on the microstructures that have been shown in Figure 3. It was observed that the tensile strength of the alloys treated below the $\beta$ transus temperature $\left(920-960^{\circ} \mathrm{C}\right)$ is significantly higher than those treated in temperature above $980^{\circ} \mathrm{C}$. The alloys by solid solution treatment at $960^{\circ} \mathrm{C}$ have the lowest average elastic modulus $(99.69 \mathrm{GPa})$. In contrast, the plasticity of the alloys does not show strong microstructure dependence. As expected, these results clearly show that the content and size of the $\alpha$ and $\beta$ phases can significantly affect the mechanical properties of the alloys with different solid solution treatment temperature. Additionally, the curve in Figure 4 further implies that the lamellar $\alpha$ phase rather than the primary $\alpha$ phase and residual $\beta$ phase is the main factor affecting the tensile strength of the alloys. The primary $\alpha$ phase seems to have little effect on the strength of the alloy. This agrees with the reported results [18]. Niinomi et al. [25] proposed that the yield strength of $\beta$ type alloys increased with increasing prior $\beta$ grain size and attributed the increase of the yield strength to the effect of precipitated $\alpha$ rather than $\beta$ grain size. However, the results in the present study show that the strength of the alloys decreases with the mobility of the prior $\beta$ phase grain boundaries, which is consistent with the reported results [19]. It is known that under the air-cooling condition, the growth of $\beta$ grains accompanies a full growth of the lamellar $\alpha$ phase in the Ti6Al4V alloys. As the thickness of the lamellar $\alpha$ phase increases, the $\alpha / \beta$ phase boundaries and the dislocation slip resistance decreases [19]. This subsequently makes the dislocations difficult to pile up and decrease the strength of as-treated alloys. Similar mechanisms have been proposed by Donachie et al. [20] that the strength of titanium alloys has a strong dependence on the number and fineness of the $\alpha / \beta$ phase boundaries. 


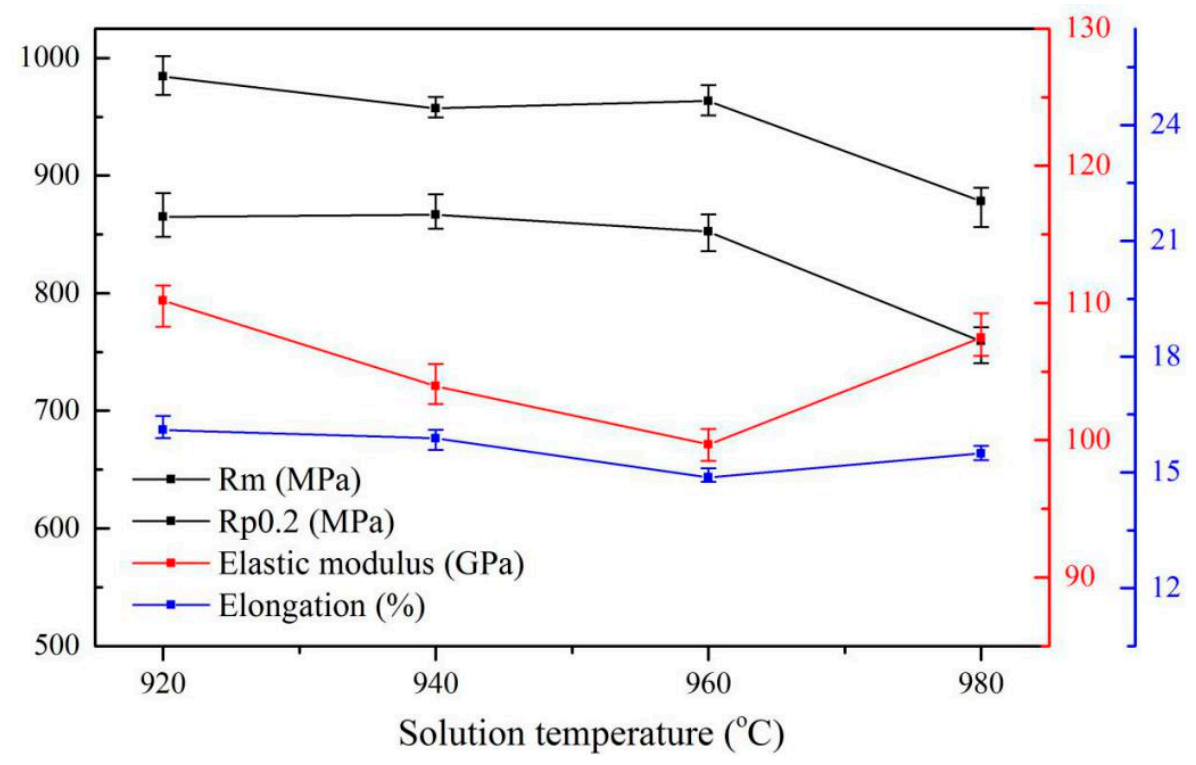

Figure 5. Mechanical properties of microstructures obtained by different solution treatments.

Figure $6 \mathrm{a}, \mathrm{b}$ are the BSE (Back scattered Electron Imaging) images of the microstructures of the Ti6Al4V alloys treated by solid solution treatment at $940{ }^{\circ} \mathrm{C}$ and $980^{\circ} \mathrm{C}$, respectively. The bright and dark regions denote the $\beta$ phase and $\alpha$ phase, respectively. As shown in Figure $6 a, b$, it is obvious that the thickness of the lamellar $\alpha$ phase in the Ti6Al4V alloys increases significantly after the solution treatment at $980^{\circ} \mathrm{C}$. The average thickness of the lamellar $\alpha$ phase increases by $1.09 \mu \mathrm{m}$ for the alloys treated at $980^{\circ} \mathrm{C}$ comparing with the alloys treated at $920^{\circ} \mathrm{C}$. It can be determined that the average tensile strength of the specimen solution-treated at $920^{\circ} \mathrm{C}$ decreases significantly from $984.11 \mathrm{MPa}$ to 878.15 MPa of the specimen solution-treated at $980^{\circ} \mathrm{C}$. It is ascribed to the large increase in the content and thickness of lamellar $\alpha$, roughly $140 \%$ and $202 \%$ respectively. However, the elongation of the alloys just changes slightly and remains about $15 \%$, a value that is consistent with the reported [19] ones $(13.25 \% \sim 17.75 \%)$. In contrast, the elastic modulus of the alloys first decreases, and it subsequently increases with increasing solution temperature, a trend that is consistent with that of the residual $\beta$ phases shown in Figure 4a. Several reports [30-32] have shown that the elastic modulus of the $\beta$ phases in the titanium alloys is nearly $80 \mathrm{GPa}$, which is lower than that of the $\alpha$ phase ( 120 GPa). Therefore, the increase of the $\beta$ phase content in titanium alloys can reduce the elastic modulus of the titanium alloys. After solution treatment at $960^{\circ} \mathrm{C}$, the average elastic modulus of the alloys is 99.69 GPa, lower than other solid solution treated specimens, which results from the maximum $\beta$ phase content $(40.2 \%)$ in the Ti6Al4V alloys.

It is noticed that the microstructure of the as-received Ti6Al4V alloys (Figure 2) and their counterparts treated by solid solution treatment at $920{ }^{\circ} \mathrm{C}$ (Figure 3a) presents obvious differences. For example, the shape of primary $\alpha$ phases in these two alloys are elongated and equiaxed; the $\beta$ phase content in these alloys is $8.38 \%$ and $15.1 \%$ respectively, which is significantly different as well. However, the elastic modulus of the alloys with significant different microstructure is almost the same ( $110 \mathrm{GPa})$, which does not decrease significantly with the increase of the $\beta$ phase content in the alloys. It is possible that the orientation of the $\alpha$ phase could play an important role in affecting the elastic modulus of the Ti6Al4V alloys. It was reported [31] that the $\alpha$ phase has strong elastic anisotropy in two-phase titanium alloys. Therefore, it is believed that both the orientation of the $\alpha$ phase and $\beta$ phase content could determine the elastic modulus of the Ti6Al4V alloys. 

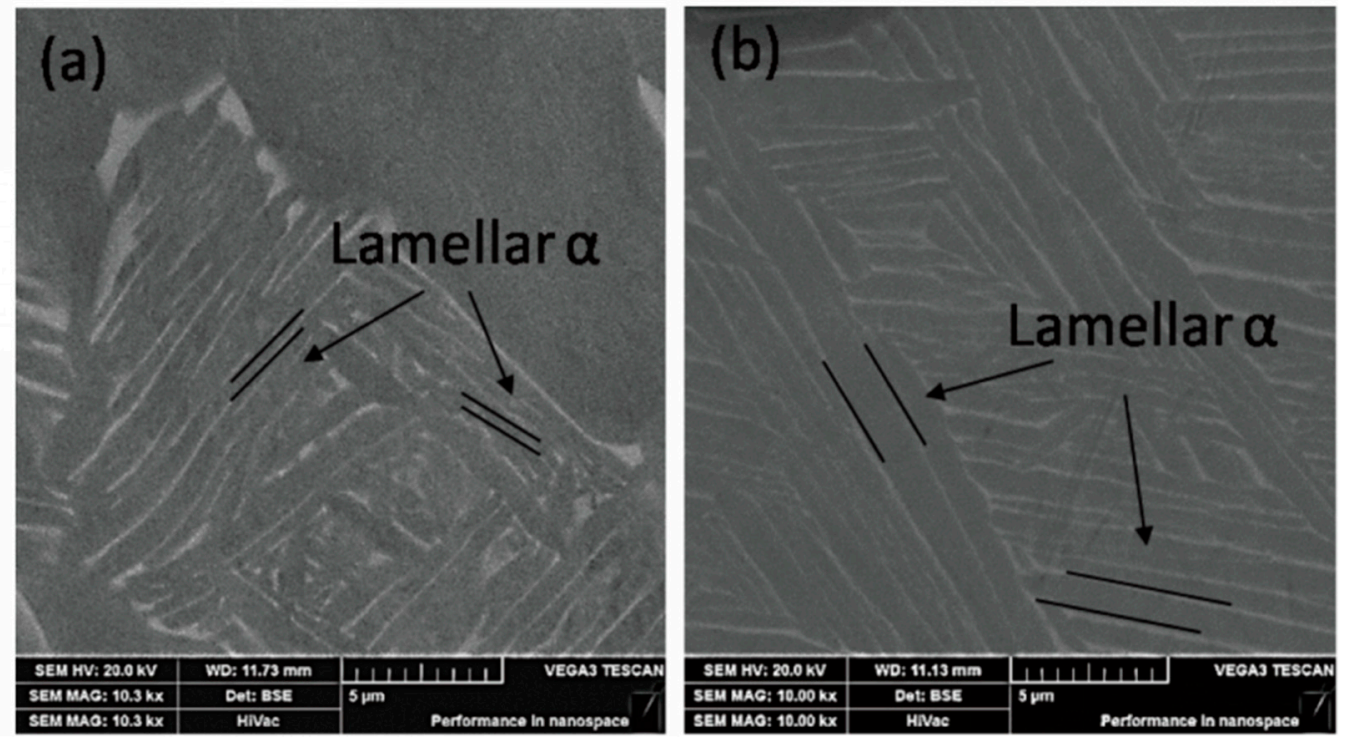

Figure 6. BSE image of microstructures obtained by different solid solution treatment: (a) $940{ }^{\circ} \mathrm{C} \times 1 \mathrm{~h}$, $\mathrm{AC}$; and (b) $980^{\circ} \mathrm{C} \times 1 \mathrm{~h}, \mathrm{AC}$.

To further analyze the orientation of the $\alpha$ phase, the texture of the $\alpha$ phase in the as-received and the solution-treated Ti6Al4V alloys are observed by EBSD and X-ray diffraction analysis, respectively, as shown in Figures 7 and 8. Figure 7a-d show the morphology of the rolling plane, and the IPF sheet and pole figure of as-received alloys respectively. It is obvious that there are $\left\{\begin{array}{llll}0 & 0 & 0 & 1\end{array}\right\}$ textures of $\alpha$ phases in the as-received alloys as shown in Figure $7 \mathrm{c}, \mathrm{d}$. This observation is consistent with the calculation pole figure as shown in Figure 8a. However, the textures of $\alpha$ phases in the alloys gradually disappear, after solid solution treatment at a temperature above $920^{\circ} \mathrm{C}$, as shown in Figure $8 \mathrm{~b}$,c. These results are consistent with those shown in Figures 2 and 3 in which the primary $\alpha$ phases of as-received alloys transformed into equiaxed shapes from elongated shapes after solid solution treatment.

It has been pointed out [30] that the $c: a$ of the HCP titanium ( $\alpha$ phase) is 1.59, which is less than the ideal value (1.63) because the $a$ is longer, resulting into the atomic distance in the basal plane (0001) increase and the interatomic forces decrease, respectively. The elastic modulus of this plane therefore decreased. The $\left\{\begin{array}{lllll}0 & 0 & 0 & 1\end{array}\right\}_{\alpha}$ textures appear in the as-received alloys, which means that the $\{0001\}_{\alpha}$ (showing lower elastic modulus) parallel to the rolling plane (test direction) is beneficial to reduce the elastic modulus of the Ti6Al4V alloys.

As shown in Figure 8a,b, the $\alpha$ phase textures of the as-received Ti6Al4V alloys disappear after solid solution treated at $920^{\circ} \mathrm{C}$, which might lead to an increase in the elastic modulus of the alloys. However, the residual $\beta$ phase content gradually increases with the solid solution temperature increased to $920^{\circ} \mathrm{C}$ and cause a decrease of elastic modulus of the alloys. These two factors together lead to the elastic modulus of as-received alloys and the alloys solid solution treated at $920{ }^{\circ} \mathrm{C}$ is basically the same. 

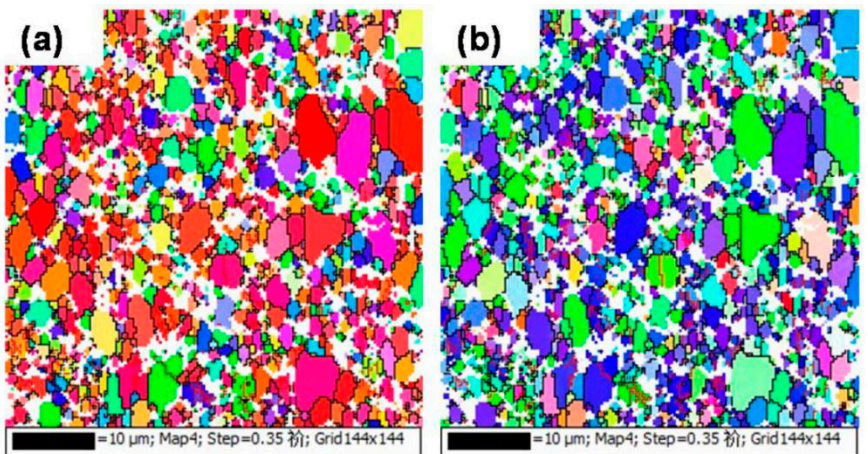

(c)
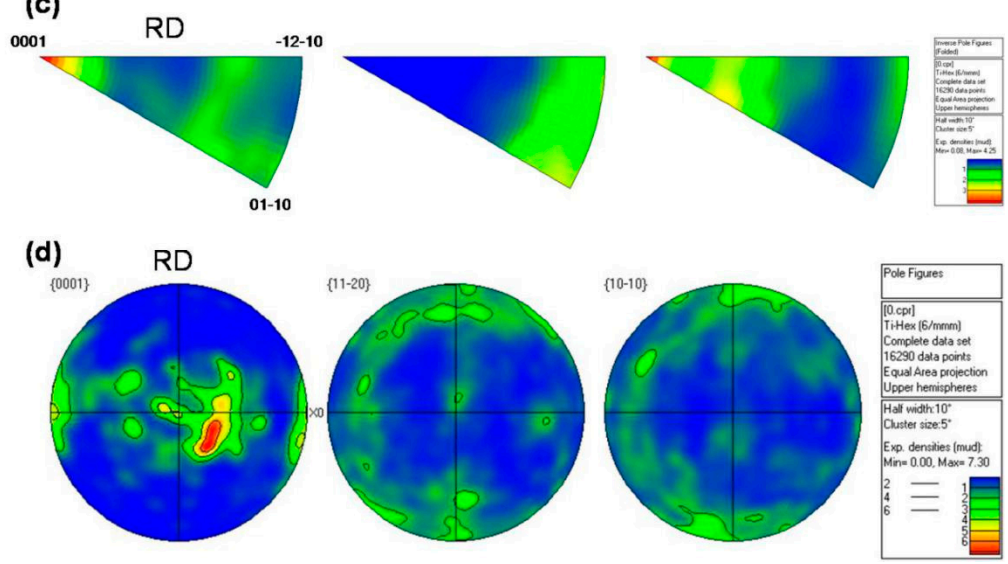

Figure 7. The EBSD results showing the microstructure and texture distribution of the $\alpha$ phase of the as-received alloys: $(\mathbf{a}, \mathbf{b})$ inverse pole figure (IPF) map from RD and TD direction; (c) inverse pole figure (IPF) sheet and (d) pole figure (PF).
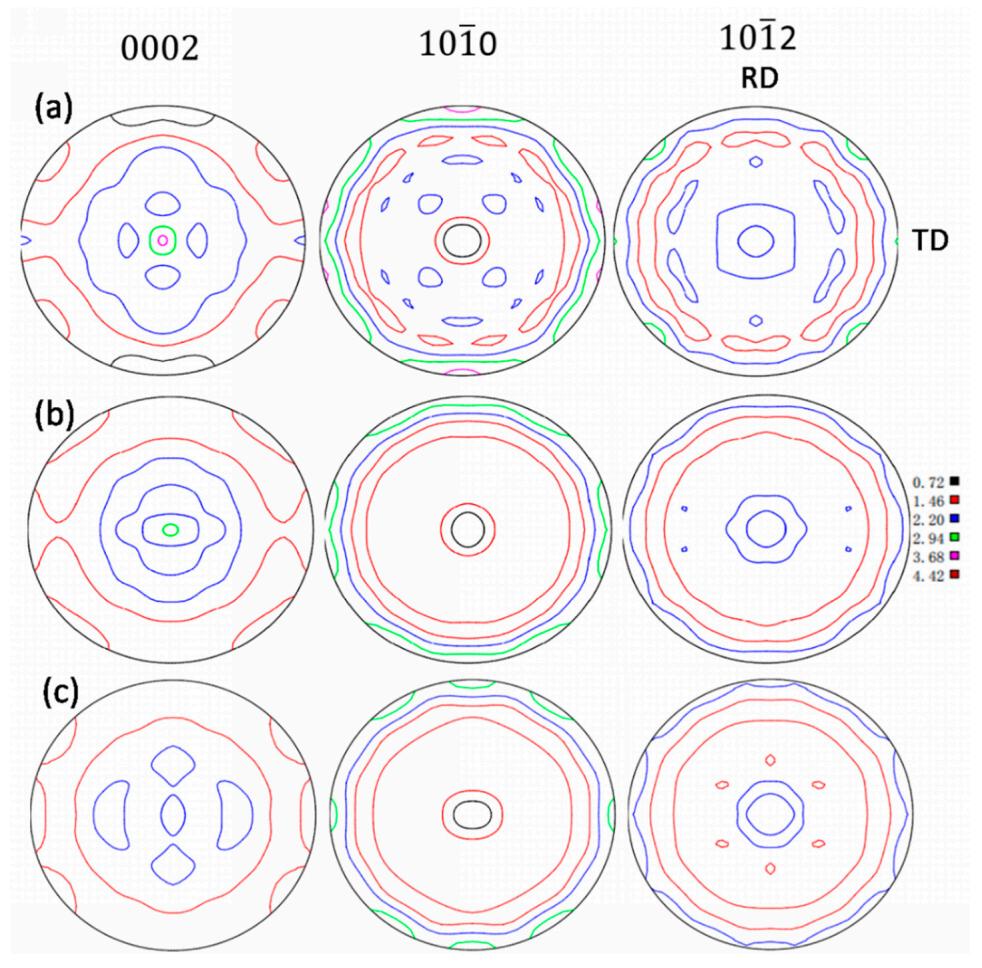

Figure 8. Pole diagram of different microstructure: (a) as-received Ti6Al4V alloy; (b) $920{ }^{\circ} \mathrm{C} \times 1 \mathrm{~h}$, AC solid solution treatment; and (c) $940{ }^{\circ} \mathrm{C} \times 1 \mathrm{~h}$, AC solid solution treatment. 


\subsection{Microstructure and its Mechanical Properties after Aging Treatment}

To further analyze the influence of the $\alpha$ and $\beta$ phase content and their size on the mechanical properties of the Ti6Al4V alloys, the specimen subjected to solution treatment at $960{ }^{\circ} \mathrm{C}$ was further treated by aging treatment. The microstructure of the alloys after aging treatment consists of primary $\alpha$ phase, lamellar $\alpha$ phase, and residual $\beta$ phase, as shown in Figure 9 . The microstructure of the Ti6Al4V alloys still retains the bimodal characteristics after aging at different temperatures, with no significant difference in morphology. After aging treatment, the content of the primary $\alpha$ phase $(\sim 39 \%)$ increases slightly compared with the alloys $(\sim 36 \%)$ treated by the solid solution treatment at $960{ }^{\circ} \mathrm{C}$. At the same time, the average size of the primary $\alpha$ grain of the alloys after aging-treated at $600{ }^{\circ} \mathrm{C}$ increases to $1.78 \mu \mathrm{m}$ compared with the specimen solution-treated at $960^{\circ} \mathrm{C}$. Statistical data on the content and size of each phase in the aging microstructure is shown in Figure 10. It is stressed that when the aging temperature increases to $750{ }^{\circ} \mathrm{C}$ from $600{ }^{\circ} \mathrm{C}$, the volume fraction and size of the primary $\alpha$ phase remains unchanged at about $39 \%$ and $11 \mu \mathrm{m}$. These results show that in a certain aging temperature range, the volume fraction and size of the primary $\alpha$ phase in the Ti6Al4V alloys have no significant dependence on the aging temperature, a conclusion that is consistent with the observation that the volume fraction of the primary $\alpha$ is mainly affected by the solution temperature [18]. In contrast, when the aging temperature increases to $750{ }^{\circ} \mathrm{C}$ from $600{ }^{\circ} \mathrm{C}$, the thickness of the lamellar $\alpha$ phase increases and the content of the $\beta$ phase decreases slightly. The average thickness of the lamellar $\alpha$ phase increases to $1.17 \mu \mathrm{m}$ from $0.836 \mu \mathrm{m}$. It is possible that the enhanced aging temperature is favorable to the phase transformation of the metastable $\beta$ phase into the lamellar $\alpha$ phase.
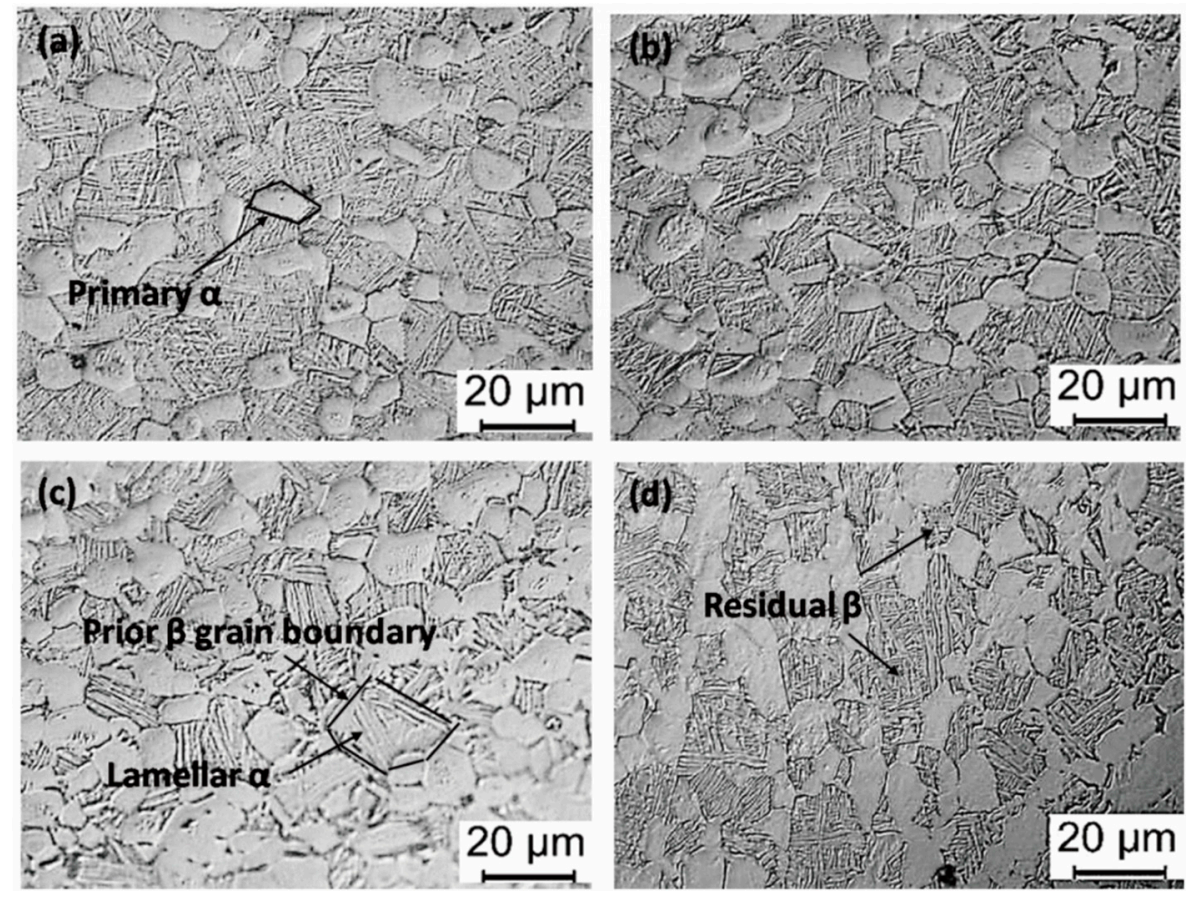

Figure 9. Microstructure under the different solution treatments followed by aging. (a) $960{ }^{\circ} \mathrm{C} \times 1 \mathrm{~h}$, $\mathrm{AC}+600{ }^{\circ} \mathrm{C} \times 2 \mathrm{~h}, \mathrm{AC}$; (b) $960^{\circ} \mathrm{C} \times 1 \mathrm{~h}, \mathrm{AC}+650{ }^{\circ} \mathrm{C} \times 2 \mathrm{~h}, \mathrm{AC} ;(\mathrm{c}) 960{ }^{\circ} \mathrm{C} \times 1 \mathrm{~h}, \mathrm{AC}+700{ }^{\circ} \mathrm{C} \times 2 \mathrm{~h}$, $\mathrm{AC}$; and (d) $960^{\circ} \mathrm{C} \times 1 \mathrm{~h}, \mathrm{AC}+750^{\circ} \mathrm{C} \times 2 \mathrm{~h}, \mathrm{AC}$. 

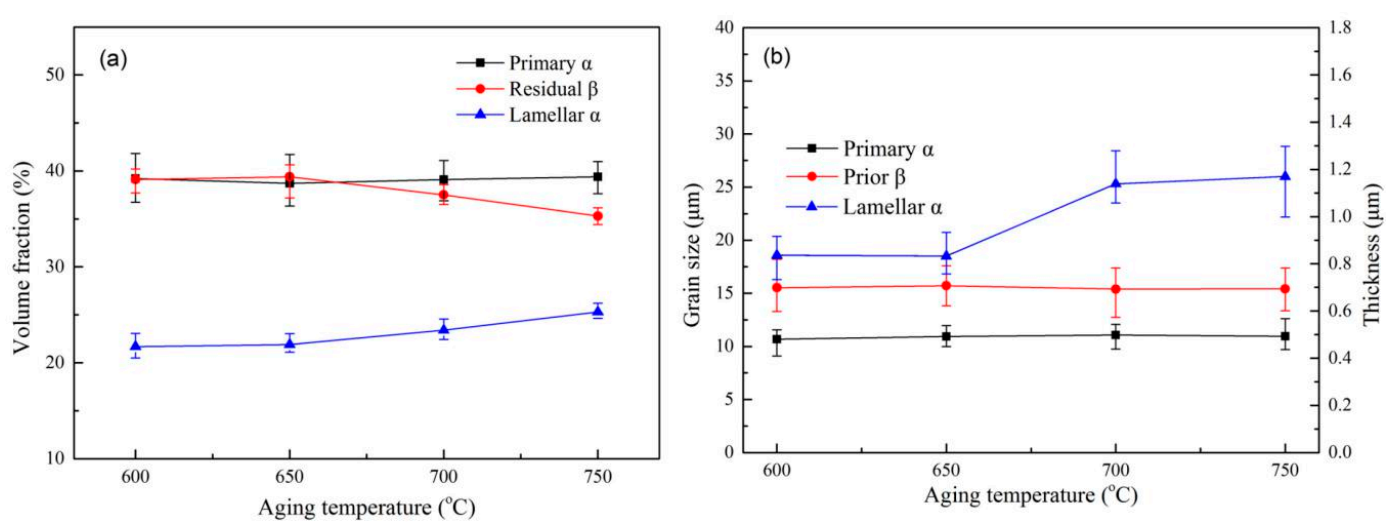

Figure 10. Microstructure statistics (a) volume fraction of $\alpha, \beta$ phase under different aging temperature and (b) grain size and thickness of $\alpha, \beta$ phase under different aging temperature.

After aging treatment, the plasticity of the specimen does not change much compared with the alloys treated by the solid solution treatment at $960{ }^{\circ} \mathrm{C}$, and the elongation remains at about $16 \%$, while the tensile strength and the elastic modulus of the alloys increase. One possible reason is that the metastable $\beta$ decomposed into the $\alpha$ phase during the aging process, which can enhance the tensile strength of the alloys. The decrease in residual $\beta$ leads to an increase in the elastic modulus of the alloys. The mechanical properties of the alloys after aging treatment are shown in Figure 11. The results show that the tensile strength of the specimens slightly decreased from $1009.72 \mathrm{MPa}$ to 956.3 $\mathrm{MPa}$ with the increase in aging temperature (from $600^{\circ} \mathrm{C}$ to $750{ }^{\circ} \mathrm{C}$ ), which may be attributed to the increase in the content and thickness of lamellar $\alpha$, roughly $17 \%$ and $40 \%$, respectively. The growth of lamellar $\alpha$ resulting in a slight decrease in the $\alpha / \beta$ phase boundary, hence, the strength of the specimen after aging treatment was not significantly reduced. As shown in Figure 12, the trend of growth of the lamellar $\alpha$ phase with increasing aging temperature further shows that the lamellar $\alpha$ is the main factor affecting the strength of the Ti6Al4V alloy. Figure 11 also shows that as the aging temperature rose from $600{ }^{\circ} \mathrm{C}$ to $750{ }^{\circ} \mathrm{C}$, the elongation can be maintained at $16.5 \pm 0.7 \%$. At the same time, the elastic modulus increased by about $3 \mathrm{GPa}$, which is attributed to the further decrease $(\sim 5 \%)$ of the residual $\beta$ phase.

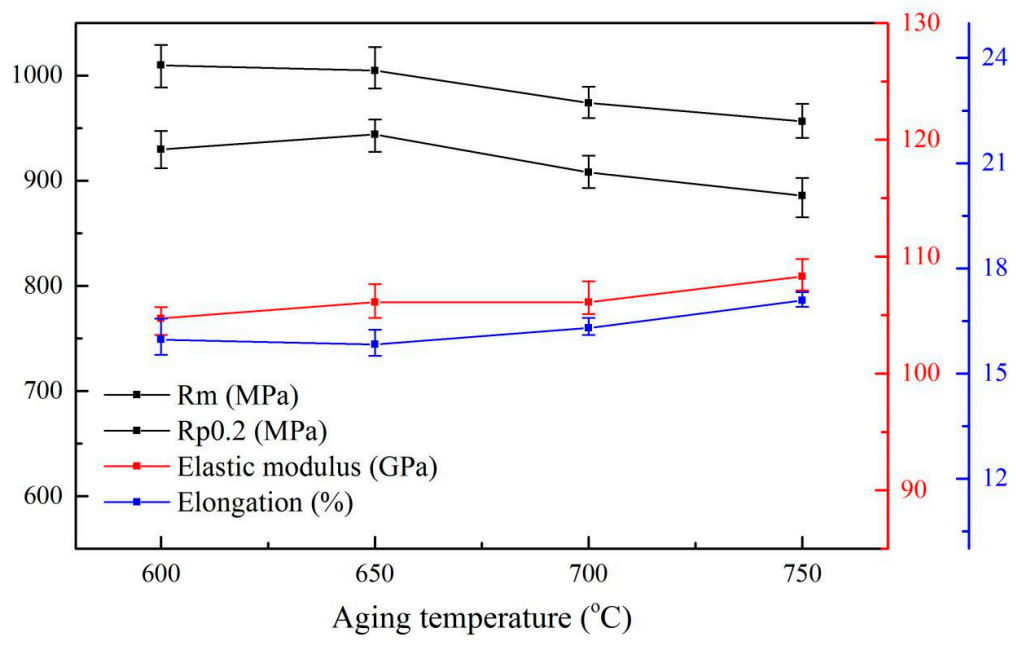

Figure 11. Mechanical properties of microstructures obtained by different aging treatments. 

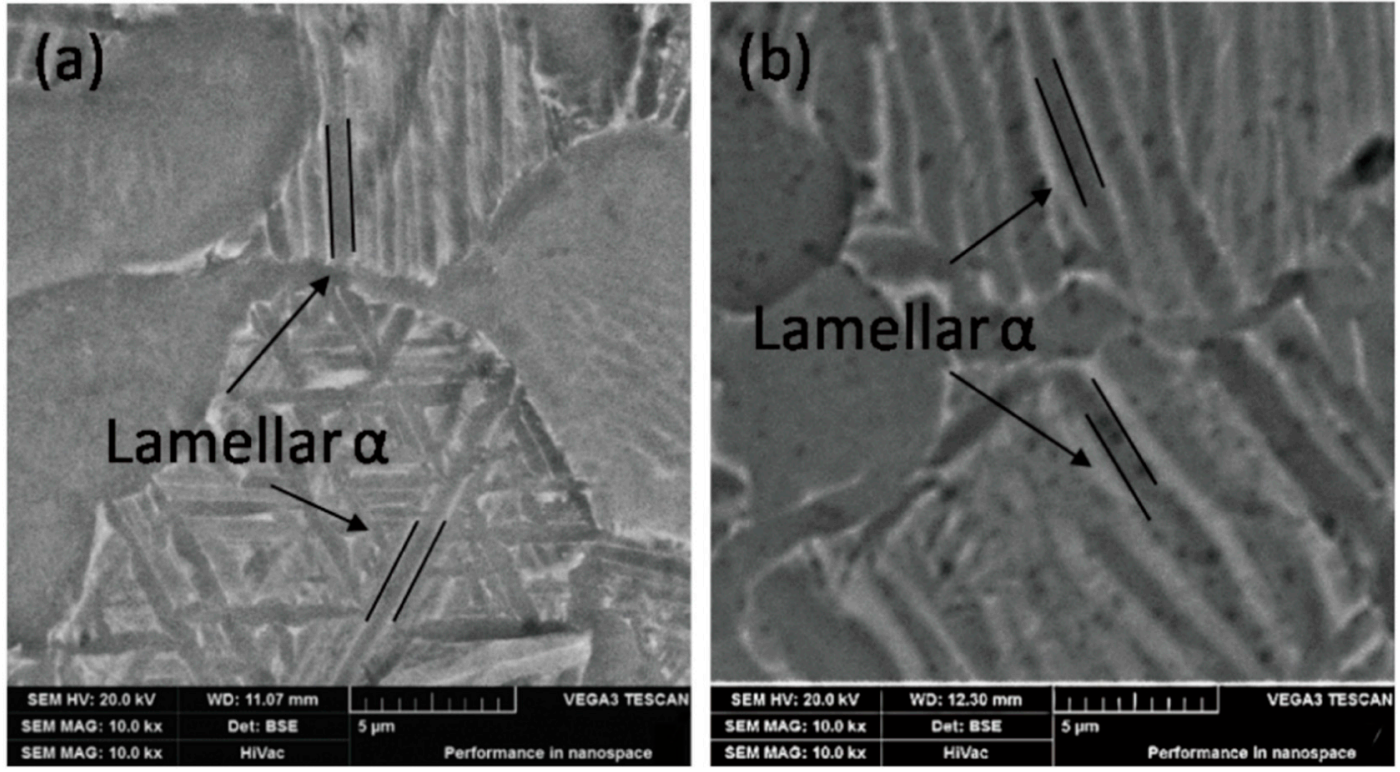

Figure 12. BSE image of microstructure under the different solution treatments followed by aging (a) $960{ }^{\circ} \mathrm{C} \times 1 \mathrm{~h}, \mathrm{AC}+600{ }^{\circ} \mathrm{C} \times 2 \mathrm{~h}, \mathrm{AC}$; (b) $960{ }^{\circ} \mathrm{C} \times 1 \mathrm{~h}, \mathrm{AC}+750{ }^{\circ} \mathrm{C} \times 2 \mathrm{~h}, \mathrm{AC}$.

\section{Conclusions}

Given the strong dependence of ultrasonic properties on the microstructure of Ti6Al4V alloys used as an ultrasonic scalpel, in this paper, the effects of solid solution and aging treatment on the microstructure and mechanical properties of Ti6Al4V alloys were studied; the following conclusions can be drawn:

1. The content and size of the primary $\alpha$ phase of the Ti6Al4V alloy decrease with an increase in solid solution temperature. The lamellar $\alpha$ phase exhibited the opposite trend, i.e., the $\beta$ phase content first increases and then decreases. The increase in the aging temperature has little effect on the content and size of the primary $\alpha$ phase but causes a slight increase in the thickness of the lamellar $\alpha$ phase.

2. For the solution and aging-treated Ti6Al4V alloys, the main factor affecting the tensile strength is lamellar $\alpha$. As the solid solution temperature increases from $960{ }^{\circ} \mathrm{C}$ to $980{ }^{\circ} \mathrm{C}$, the average thickness of lamellar $\alpha$ increased by $1.09 \mu \mathrm{m}$, and the average yield strength decreased by $93 \mathrm{MPa}$. As aging temperature increases from $600^{\circ} \mathrm{C}$ to $750{ }^{\circ} \mathrm{C}$, the thickness of lamellar $\alpha$ slightly increases by $0.33 \mu \mathrm{m}$ and causes the yield strength of the specimens remained at about $900 \mathrm{MPa}$.

3. The elastic modulus of the Ti6Al4V alloy is mainly controlled by the texture of the $\alpha$ phase and content of the $\beta$ phase. However, the $\beta$ phase content is the main factor affecting the elastic modulus of the alloys treated by solution and aging treatment. Specifically, the specimen's solid solution treated at $960^{\circ} \mathrm{C}$ has the highest residual $\beta$ content, hence the average elastic modulus is the lowest at $99.69 \mathrm{GPa}$. Additionally, the elastic modulus of the alloys after aging treatment remained at about $105 \mathrm{GPa}$, which is attributed to the stable residual $\beta$ phase content.

Author Contributions: Conceptualization, S.L. and Y.L.; methodology, Z.H.; software, Z.H.; validation, Z.H., D.L. and J.L.; formal analysis, S.L.; investigation, Z.H.; resources, Y.L.; data curation, Y.C.; writing-original draft preparation, Z.H.; writing-review and editing, Z.H.; visualization, D.L.; supervision, Y.L.; project administration, H.H.; funding acquisition, H.H. All authors have read and agreed to the published version of the manuscript.

Funding: This research was funded by the National Natural Science Foundation of China (Grant No. 51804271), Guangxi Science and Technology Plan Project (Grant No. 2017GXNSFBA198187 and 2018GXNSFAA281237).

Acknowledgments: The use of facilities in State Key Laboratory for Powder Metallurgy at Central South University is acknowledged. 
Conflicts of Interest: The authors declare no conflict of interest.

\section{References}

1. Chen, Y.; Zhou, Z.; Zhang, G. Effects of different tissue loads on high power ultrasonic surgery scalpel. Ultrasound. Med. Biol. 2006, 32, 415-420.

2. Gavin, G.P.; McGuinness, G.B.; Dolan, F.; Hashmi, M.S.J. Performance characteristics of a therapeutic ultrasound wire waveguide apparatus. Int. J. Mech. Sci. 2007, 49, 298-305. [CrossRef]

3. Chen, Y.; Luo, X.; Shi, W.; Zhou, Z. The application and development of ultrasonic scalpel. J. Biomed. Eng. 2005, 22, 377-380.

4. Wilkie, M.; Lucas, M. The effect of Ti-6Al-4V microstructure on the performance of ultrasonic soft tissue cutting tips. Proc. Meet. Acoust. 2017, 32, 020010.

5. Lobkis, O.I.; Rokhlin, S. Characterization of polycrystals with elongated duplex microstructure by inversion of ultrasonic backscattering data. Appl. Phys. Lett. 2010, 96, 161905. [CrossRef]

6. Hector, C.; Carreon, M. Assessment of precipitates of aged Ti-6Al-4V alloy by ultrasonic attenuation. Philos. Mag. 2017, 97, 58-68.

7. Bhattacharjee, A.; Pilchak, A.L.; Lobkis, O.I.; Foltz, J.W.; Rokhlin, S.I.; Williams, J.C. Correlating Ultrasonic Attenuation and Microtexture in a Near-Alpha Titanium Alloy. Metall. Mater. Trans. A 2011, 42, 2358-2372. [CrossRef]

8. Cui, G.; Liu, Y.; Gao, G.; Liu, H.; Li, S.; Kou, Z. Preparation, Mechanical Properties, and High-Temperature Wear Resistance of Ti-Al-B alloy. Materials 2019, 12, 3751. [CrossRef]

9. Cui, N.; Wu, Q.; Yan, Z.; Zhou, H.; Wang, X. The Microstructural Evolution, Tensile Properties, and Phase Hardness of a TiAl Alloy with a High Content of the $\beta$ Phase. Materials 2019, 12, 2757. [CrossRef]

10. Guo, N.; Cheng, Q.; Zhang, X.; Fu, Y.; Huang, L. Microstructure and Mechanical Properties of Underwater Laser Welding of Titanium Alloy. Materials 2019, 12, 2703. [CrossRef]

11. Lütjering, $\mathrm{G}$. Influence of processing on microstructure and mechanical properties of $(\alpha+\beta)$ titanium alloys. Mater. Sci. Eng. A 1998, 243, 32-45. [CrossRef]

12. Chong, Y.; Bhattacharjee, T.; Shibata, A.; Tsuji, N. Investigation of the grain size effect on mechanical properties of Ti-6Al-4V alloy with equiaxed and bimodal microstructures. IOP Conf. Ser. Mater. Sci. Eng. 2017, 219, 012013. [CrossRef]

13. Zherebtsov, S.; Murzinova, M.; Salishchev, G.; Semiatin, S.L. Spheroidization of the lamellar microstructure in Ti-6Al-4V alloy during warm deformation and annealing. Acta Mater. 2011, 59, 4138-4150.

14. Matsumoto, H.; Bin, L.; Lee, S.-H.; Li, Y.; Ono, Y.; Chiba, A. Frequent Occurrence of Discontinuous Dynamic Recrystallization in Ti-6Al-4V Alloy with $\alpha$ Martensite Starting Microstructure. Metall. Mater. Trans. A 2013, 44, 3245-3260. [CrossRef]

15. Matsumoto, H.; Yoshida, K.; Lee, S.-H.; Ono, Y.; Chiba, A. Ti-6Al-4V alloy with an ultrafine-grained microstructure exhibiting low-temperature-high-strain-rate superplasticity. Mater. Lett. 2013, 98, 209-212. [CrossRef]

16. Matsumoto, H.; Nishihara, T.; Velay, V.; Vidal, V. Superplastic Property of the Ti-6Al-4V Alloy with Ultrafine-Grained Heterogeneous Microstructure. Adv. Eng. Mater. 2017, 20, 1700317. [CrossRef]

17. Mironov, S.; Murzinova, M.; Zherebtsov, S.; Salishchev, G.A.; Semiatin, S.L. Microstructure evolution during warm working of Ti-6Al-4V with a colony- $\alpha$ microstructure. Acta Mater. 2009, 57, 2470-2481.

18. Ren, Y.; Zhou, S.; Luo, W.; Xue, Z.; Zhang, Y. Influence of primary $\alpha$-phase volume fraction on the mechanical properties of Ti-6Al-4V alloy at different strain rates and temperatures. IOP Conf. Ser. Mater. Sci. Eng. 2018, 322, 022022. [CrossRef]

19. Peng, X.; Guo, H.; Wang, T.; Yao, Z. Effects of $\beta$ treatments on microstructures and mechanical properties of TC4-DT titanium alloy. Mater. Sci. Eng. A 2012, 533, 55-63. [CrossRef]

20. Donachie, M.J., Jr. Titanium: A Technical Guide, 2nd ed.; ASM International: Metals Park, OH, USA, 2000; pp. 95-121.

21. Ankem, S.; Margolin, H.; Greene, C.A.; Neuberger, B.W.; Oberson, P.G. Mechanical properties of alloys consisting of two ductile phases. Prog. Mater. Sci. 2006, 51, 632-709. [CrossRef] 
22. Peng, X.N.; Guo, H.Z.; Shi, Z.F.; Qin, C.; Zhao, Z.L. Microstructure characterization and mechanical properties of TC4-DT titanium alloy after thermomechanical treatment. Trans. Nonferrous Met. Soc. China 2014, 24, 682-689. [CrossRef]

23. Guo, P.; Zhao, Y.; Zeng, W.; Hong, Q. The effect of microstructure on the mechanical properties of TC4-DT titanium alloys. Mater. Sci. Eng. A 2013, 563, 106-111. [CrossRef]

24. Vrancken, B.; Thijs, L.; Kruth, J.-P.; van Humbeeck, J. Heat treatment of Ti6Al4V produced by Selective Laser Melting: Microstructure and mechanical properties. J. Alloys Compd. 2012, 541, 177-185. [CrossRef]

25. Niinomi, M.; Kobayashi, T. Fracture characteristics analysis related to the microstructures in titanium alloys. Mater. Sci. Eng. A 1996, 213, 16-24. [CrossRef]

26. Standardization Administration of the P.R.C. GB/T 6394-2017: Determination of Estimating the Average Grain Size of Metal; Standardization Administration of the P.R.C.: Beijing, China, 2017.

27. Standardization Administration of the P.R.C. GB/T 228.1-2010: Metallic Materials-Tensile Testing-Part 1: Method of Test at Room Temperature; Standardization Administration of the P.R.C.: Beijing, China, 2010.

28. Standardization Administration of the P.R.C. Metallic Materials-Determination of Modulus of Elasticity and Poisson's Ratio; Standardization Administration of the P.R.C.: Beijing, China, 2008.

29. Zhang, S.Z.; Liu, Z.Q.; Wang, G.D.; Chen, L.Q.; Liu, X.H.; Yang, R. Microstructural evolution during aging of Ti-5Al-5Mo-5V-1Cr-1Fe alloy. J. Cent. South Univ. Technol. 2009, 16, 354-359. [CrossRef]

30. Marker, C.; Shang, S.-L.; Zhao, J.-C.; Liu, Z.-K. Elastic knowledge base of bcc Ti alloys from first-principles calculations and CALPHAD-based modeling. Comput. Mater. Sci. 2017, 140, 121-139. [CrossRef]

31. You, L.; Song, X. First principles study of low Young's modulus Ti-Nb-Zr alloy system. Mater. Lett. 2012, 80, 165-167. [CrossRef]

32. You, L.; Song, X. A study of low Young's modulus Ti-Nb-Zr alloys using d electrons alloy theory. Scr. Mater. 2012, 67, 57-60. [CrossRef]

(C) 2020 by the authors. Licensee MDPI, Basel, Switzerland. This article is an open access article distributed under the terms and conditions of the Creative Commons Attribution (CC BY) license (http://creativecommons.org/licenses/by/4.0/). 